\title{
Kodon-Kodon Hotel Resort With Neo Vernacular Approach
}

\author{
F. Eddy*and M. Haris \\ Architecture Department, Faculty of Engineering, Universitas Sumatera Utara, Medan, Indonesia \\ ^email: firman2@usu.ac.id \\ Submitted: 15 January 2020 Revision: 25 January 2020 Online: 30 January 2020
}

\begin{abstract}
Resort hotels are usually built in tourist areas such as mountains, beaches, and lakes. The problem in this design is that contoured land becomes more difficult in designing compared to flat land. But how to create an advantage on the contoured land, and how to create a design and building in accordance with the title raised and the purpose of that is to support the existence of functions building according to the project case. The purpose of designing this Resort Hotel is to increase the number of foreign and local tourists who come to North Sumatra especially to the Lake Toba area and provide temporary shelter and recreational activities for the community and tourists who come. The method used is to apply the local wisdom of the Karo tribe. The shape of the roof at the Karo traditional house is applied to the hotel which has been designed and the use of ornaments as facades on building looks to apply the neo-vernacular architectural theme. The results of the design of Resort Hotels to attract tourists to visit this Hotel and the Hotel also aims to preserve the local wisdom of Karo tribes. "Hotel Resort Kodon" is present as a place or recreational facility that can meet the needs of tourists where the Lake Toba area requires many new lodging and recreation areas.
\end{abstract}

Keywords: architecture, local wisdom, neo-vernacular, resort hotels

\section{INTRODUCTION}

Tourism is one of the promising income factors for countries in increasing their sources of income. Currently, Indonesia is also in the process of promoting its tourism to attract the attention of other countries, this is intended to make Indonesia increasingly famous for citizens/residents of other countries to visit Indonesia. By promoting Indonesia by selling tourism and cultural diversity in Indonesia, this was responded well by a large number of foreign tourists visiting Indonesia. In addition to the many beaches and mountains that attracted local and foreign tourists, the Lake was no less interesting as place tours, like the Lake Toba. Lake Toba can increase foreign tourists who want to enjoy the panoramic view of Lake Toba with a distance not too far from the center of Medan City. And for now, Silangit Airport has been built to make it easier for foreign and local tourists to go to Lake Toba. North Sumatra as one of the best tourist destinations or destinations in Indonesia, still lacks star-rated hotel rooms to anticipate the flow of tourists or the surge of foreign tourists in the future, "Kodon-Kodon Hotel Resort" present as a place or recreational facility that meets the needs of tourists, where the Lake Toba area requires many new lodging and recreation areas.

According to Nyoman. Pendit. Ilmu Pariwisata, Jakarta: Trisakti Tourism Academy, 1999, Resort is a place to stay where you have special facilities for leisure activities and sports such as tennis, golf, spa, tracking, and jogging, the concierge is experienced and knows the resort environment well, if there are guests those who want to hitch-hike around while enjoying the natural beauty around this resort.

Hotels in the Jimbaran area, Uluwatu, Bali. Hotels located on the beach of Uluwatu. This hotel was built in 2012. The hotel consists of 5 floors. It is located near the sea but not directly adjacent. View in hotel rooms leads to the sea. The hotel rooms are 118 rooms and have one bar, two restaurants and several other supporting facilities (Figure 1). 


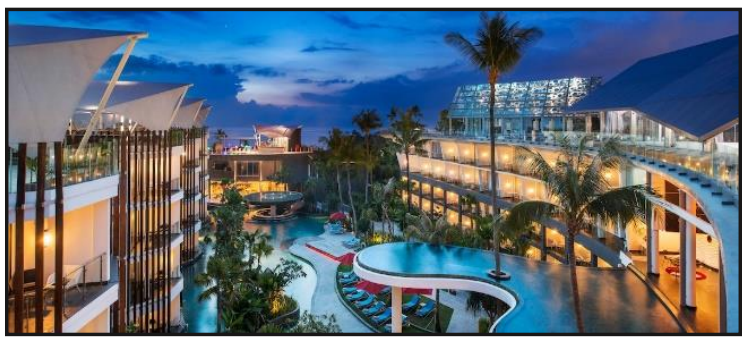

Figure 1. Hotel Lemeridian Jimbaran Bali (Source: www.lemeridienbalijimbaran.com)

The mosque building that was designed by Rizal Muslimin, is the architect of the winner of the West Sumatra Grand Mosque design competition which was attended by 323 famous architects from other countries in 2007. West Sumatra Grand Mosque is considered the largest mosque in West Sumatra and a new landmark for the province of West Sumatra. The mosque which has a capacity of 20,000 worshipers is also designed as a location shelter to evacuate the tsunami victims on the 2 nd and 3rd floors. This mosque is a Neo-Vernacular building by combining elements from traditional houses with modern elements (Figure 2).

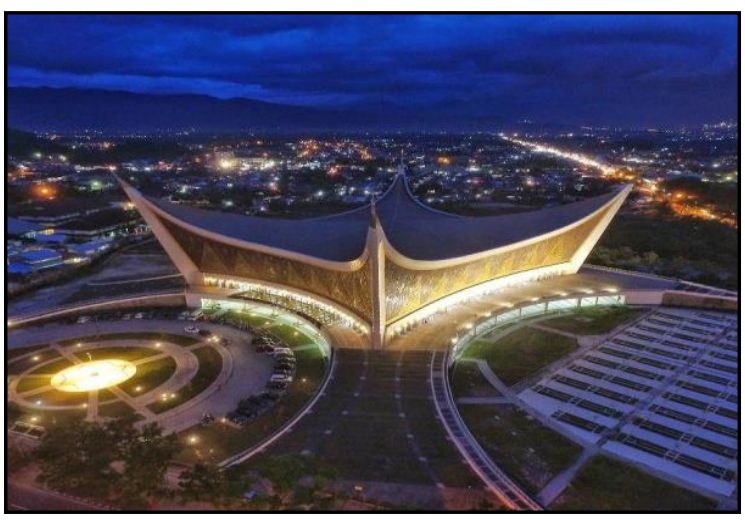

Figure 2. Masjid Raya Sumatera Barat (Source:

http://khatulistiwatravel.com/artikel/4109/8fakta-unik-masjid-raya-sumatera-barat-yangharus-kamu-ketahui.html)

The Minangkabau traditional house is known as the "Rumah Gadang" (Large House). The building construction structure shows the pattern of the Rumah Gadang with a triangle pattern down, the roof inspired by the roof of the Gadang house is called Mambasuik Bumi. carvings in the Gadang house. The concept of building interiors is from the Mihrab, Liwan and Sahn sections. The shape of the Mihrab in this mosque has a round shape resembling an egg that reminds us of the form of Hajar Aswad in Mecca. The form of Liwan in the mosque was designed to be very sturdy and very clean using concrete and ceramics. For the part the ceiling is made known as Asmaul Husna (the names of Allah) in the Liwan section there is an arrangement of lights to show the modern and not traditional form of the mosque. Sahn or (place of ablution) in the mosque is made simple using darker and more open colors so that air circulation goes well is also environmentally friendly. Rainwater utilization system that makes ablution place become environmentally friendly (Figure 3 ).

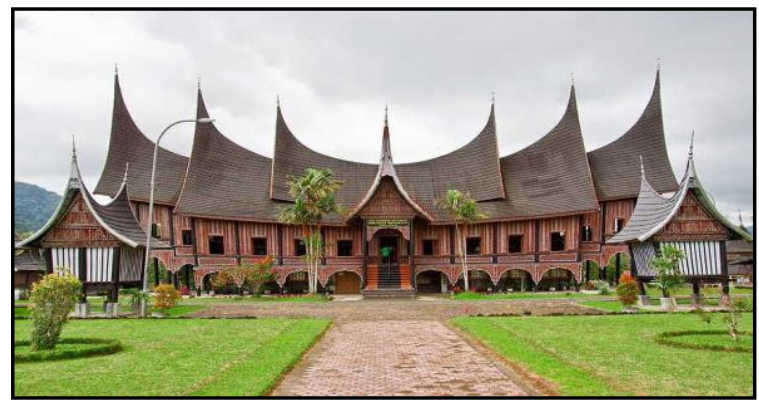

Figure 3. Rumah gadang

(Source:

https://www.arsitag.com/article/rumah-gadangrumah-tradisional-minangkabau)

\section{METHODS}

The method consists of a set of principal design discussions on data collection, is the type of design method, data analysis, data source, design location selection, the chosen design method is the qualitative method, in which the selection of Hotel Resort design locations need to be considered comfort and strategic placement. Qualitative methods for designing Resort Hotels because they are rational, in which each process has been planned systematically in accordance with the conditions of the location conditions.

\section{RESULTS AND DISCUSSION}

In terms of the macro site in the brand district, Karo regency, North Sumatra Province region from the north bordering the District of Karo District, the border area from the south borders Silahi District Sabungan Dairi regency, boundary to the west of the Karo regency brand 
district, the boundary of the area from the east is based on the Karo District Brand District. This traditional house has become a focus in the application of buildings in Kodon-Kodon Hotel Resort, where the buildings in the KodonKodon Hotel Resort use touches from this traditional house, but as a form of mass and layout, the buildings remain in a more modern form and material. The Mass Concept for the Kodon-Kodon Hotel Resort building uses an approach to the local cultural wisdom of the Karo people. Form on the mass formed from traditional Karo architectures that have been modified in such a way with more modern materials, the roof of the Karo traditional house is chosen to be applied to the main building and supporting buildings to create an impression of local wisdom in the building (Figure 4).

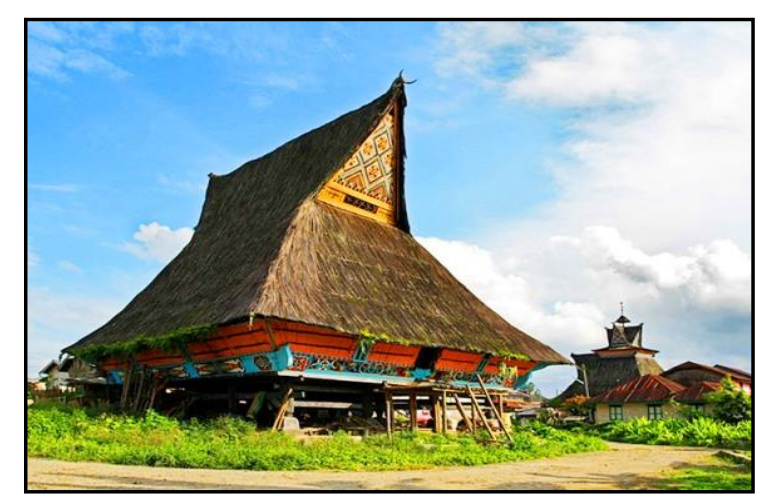

Figure 4. Rumah adat Siwaluh Jabu (Source:

https://www.triptrus.com/destination/529/ruma h-adat-batak-karo)

The use of solar panels in hotels serves as a power plant for garden lights. the roof that is used in the hotel is the roof in the building of the wall, showing the existing local wisdom (Fig. 5).
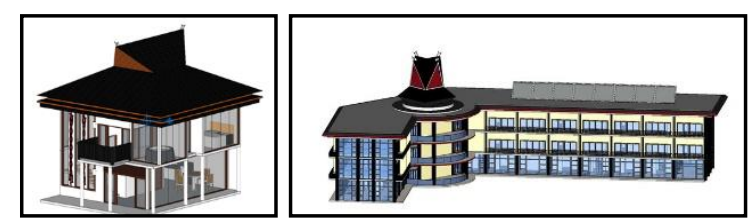

Figure 5 and 6. Composition of the masses (source: 2018)

Ornaments on the villa are placed on the front of the building so as to highlight local wisdom and also the use of the roof that is exactly the roof of the gray building (Figure 6).
Formed the hotel building to take a seat from Karo ornaments, namely Sulaiman's footprint, the name of the ornament was taken from a king who was considered magic, respected and feared by evil creatures, Sulaiman footprint ornaments believed to help Karo people to avoid the threat of evil intentions, both come real or unreal. This ornament has the meaning of family and strength meaning (Fig. 7).

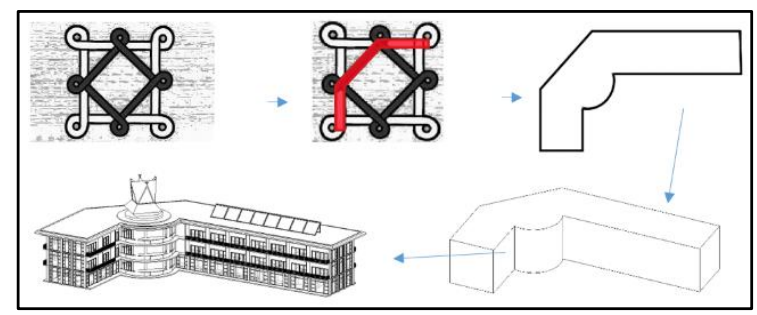

Figure 7. Building

(Source: 2018)

\section{CONCLUSION}

With the increasing interest of tourists to explore the area of Lake Toba, Resort is an alternative as a place that facilitates all the needs of tourists, and also as a place to preserve the culture of local wisdom by raising the NeoVernacular theme. Supporting facilities that can accommodate tourists, With the Kodon-Kodon Hotel Resort that provides supporting facilities with a good design, is expected to increase the number of tourists who come to the KodonKodon Village.

\section{ACKNOWLEDGMENT}

This journal Hotel Resort Kodon-Kodon was made to provide solutions, concepts, and responses to the village Kodon-Kodon locations planned to be built by Resort Hotels by organizers of Taman Simalem Resort, Karo Regency, North Sumatra.

\section{REFERENCES}

[1] Nyoman.S.Pendit., "Ilmu Pariwisata, Jakarta: Akademi Pariwisata Trisakti," 1999.

[2] Buaton, K. W. S., \& Purwadio, H."Kriteria Pengembangan Kawasan Wisata Danau," (2015). 
